\title{
Erratum to: Estimation of elbow flexion force during isometric muscle contraction from mechanomyography and electromyography
}

\author{
Wonkeun Youn · Jung Kim
}

Published online: 18 September 2010

(C) International Federation for Medical and Biological Engineering 2010

\section{Erratum to: Med Biol Eng Comput}

DOI 10.1007/s11517-010-0641-y

In the above-mentioned article the definition of MAV was erroneously published as 'Mean Average Value'. The correct definition of MAV is 'Mean Absolute Value'.

The online version of the original article can be found under doi:10.1007/s11517-010-0641-y.

W. Youn · J. Kim (ه)

School of Mechanical Aerospace \& Systems Engineering,

Division of Mechanical Engineering, KAIST, Daejeon,

Republic of Korea

e-mail: jungkim@kaist.ac.kr

W. Youn

e-mail: won13y@kaist.ac.kr 